lowing plan of action. First, to set limitations on the kinds of books to be suggested; second, to canvass the membership for titles; third, to compile a list of the results and arrange for its distribution to interested publishers and to the membership.

The following criteria were established for titles to be submitted.

1) books should not be dependent wholly on illustrations which might reproduce poorly;

2) the copyright should have expired;

3 ) the books should be of scholarly appeal (i.e., monographs, source books, etc.);

4) long runs would not be eligible; a volume or two or a periodical might be acceptable, but not a lengthy run.

In general, the type of material to be considered was to include early guide books, catalogues of holdings of cities and museums, early catalogues raisonnes, sales catalogues of historic firms, diaries and biographies by artists and their contemporaries which referred directly to the art life of the times, and early books and monographs on the theory of art.

The present committee plans to bring the following list to the direct attention of the editors of art reprint publishers and microfilm firms.Committee on Microfilm and Reprints, Art Subsection, Subject Specialists Section, ACRL.

\section{TITLES SUGGESTED BY THE ART SUBSECTION FOR REPRINTING}

Adams, Charles Francis. Letters and papers of John Singleton Copley. Boston, 1914. (Mass. Hist. Soc. Collections, v. 71)

Albrizzi, Isabella. Opere di scultura e di plastica di Antonio Canova. Pisa, Capurro, 18211824. 4 vols. (or English translation by H. G. Bohm, London, 1849)

Alison, Archibald. Essays on the nature and principles of taste. (Editions from 17961856 ). ca. 400 p. $22 \mathrm{~cm}$. No illus.

Baldinucci, Filippo. Cominciamento e progresso dell'arte dell'intagliare in rame. Florence, 1767 (or 1st ed., 1686).

Barbaro, Daniele. La practica della perspettiva. Venice, Camillo \& Rutilio Borgominieri, 1568.

Roux, Henri. Herculanum et Pompéi. Recueil général des peintures, bronzes, mosaïques, etc. découverts jusqu'à ce jour, et reproduits d'après Le Antichita di Ercolano, Il Museo Borbonico. . . Paris, Librairie de FirminDidot, 1861-1870. 8 vols. (or 1st ed., 1840)

Cary, Elizabeth L. The Works of James McNeil Whistler. New York, Moffatt, 1913 [c 1907]

Castiglione, Sabba da. Ricordi overo ammaestramenti. Venice, Paolo Gherardo, 1555. (or, 1st ed., 1546. Prefer the 1555 edition, which is amplified with a total of 133 'ricordi').

Clement, Clara Erskine and Hutton, Laurence. Artists of the 19th century and their works. Boston, Houghton, 1884.

Clement, Clara Erskine. Painters, Sculptors, Architects, Engravers and their works. New York, Hurd and Houghton, 1877.

Cole, Thomas. The Course of Empire, Voyage of Life and other pictures of Thomas Cole, by Louis Nobel. New York, Cornish, Lamport \& Co., 1853.

Colonna, Francesco. Hypnerotomachia Poliphili. Venice, Aldus Manutius, 1499. (For reprint in a fine edition.)

Cumberland, George. An essay on the utility of collecting the best works of the ancient engravers of the Italian school; accompanied by a critical catalogue. . . London, Payne \& Foss, 1827.

Cumberland, Richard. Anecdotes of eminent painters in Spain during the 16th and 17th centuries, with cursory remarks upon the present state of arts in that kingdom. London, Dilly, 1787.

Ffoulkes, Constance Jocelyn. Vicenzo Foppa of Brescia, founder of the Lombard School, his life and work. London, Lane, 1909.

Bertotti Scamozzi, Ottavio. Il forestiere istrutto nelle cose più rare di architettura e di alcune pitture della città di Vicenza. 2nd ed. G. Giuliani, 1804.

Girardin, Louis Stanisla Cécile Xavier. Itinéraire des jardins d'Ermenonville. Paris, Merigot, 1788 .

Hamilton, Sir William. Outlines from the figures and compositions upon the Greek, Roman and Etruscan vases of the late Sir William Hamilton. Drawn and engraved by the late Mr. Thomas Kirk. London, William Miller, 1804.

Hirschfield, Christian Cajus Lorenz. Theorie der gartenkunst. Leipzig, Weidmann, 1779-1785. 5 vol.

Jackson, W. F. comp. Catalogue of paintings in the E. B. Crocker Art Gallery. Sacramento, 1905.

Jameson, Anna Brownell. Legends of the Madonna as represented in the Fine Arts. Boston, Houghton, Mifflin and Co., 1891.

- Sacred and Legendary Art as represented in the Fine Arts. Boston, Houghton, Mifflin and Co., 1896. 2 vol.

Jervis, W. P. The Encyclopedia of Ceramics. New York, n.p., 1902. Useful for contemporary information on American potteries (originally published in Crockery and Glass Journal). It is well printed on $673 \mathrm{pp}$. but very weak paper.

Knight, Richard Payne. An Analytical Inquiry into the principles of taste. London, T. Payne, 1805. 
Lairesse, Gérard de. A treatise on the art of painting . . . rev. corr. ed. London, E. Orme, 1817. 2 vols.

Lippmann, F. Zeichnungen von Albrecht Dïrer in Nachbildungen. Berlin, 1883-1929. 7 vols. A complete corpus.

Lomazzo, Giovanni Paolo. Trattato dellarte de la pittura. Milan, Pontio, 1584.

Malton, James. An essay on British cottage architecture. London, 1798.

Mander, Carel van. Das Lebend der niederländischen und deutschen Maler. Textabdruck nach der Ausgabe von 1617. Übersetzung und Anmerkungen von Hans Floerke. Munich, Müller, 1906. 2 vol.

- Het Schilder-Boek waer in ... den grondt der edel vry schilderconst in verscheyden deelen wort voorghedraghen. Haarlem, van Wesbusch, 1604.

Merrifield, Mrs. Mary Philadelphia. Original treatises, dating from the XIIth to XVIIIth centuries on the arts of painting in oil, miniature, mosaic on glass; of gilding, dyeing and the preparation of colours and artificial gems. London, J. Murray, 1849. 2 vol.

Milizia, Francesco. Le vite dépiu celebri architetti d'ogni nazione e d'ogni tempo. Rome, Komarek, 1768. (or, English translation, London, J. Taylor, 1826).

New York. Metropolitan Museum of Art. Paintings by Frederick Edwin Church; special exhibition, May 28th-Oct. 15th. New York, 1900.

Orlandi, Pellegrino Antonio. Abecedario pitto.. rico. Bologna, Pisarri, 1704.

Pech, James. The influence of liberty on taste in the ages of Augustus and Louis XIV. New York, Hurd and Houghton, 1869.

Sanmicheli, Michele. Li cinque ordini dell'architettura civile di Michel Sanmicheli. Verona, Jacobo Vallarsi, 1735.

Price, Sir Uvedale, bart. An essay on the picturesque as compared with the sublime and the beautiful; and on the use of studying pictures for the purpose of improving real landscape. London, Robson, 1794. (Later editions up to 1842 including other material.)

Quatremère de Quincy, Antoine Chrysosteme. Essai sur l'idéal dans ses applications practiques aux oeuvres de l'imitation propres des arts du dessin. Paris, A. Le Clère,1837.

Redford, George. Art sales. A history of sales of pictures and other works of art. . . . London, Bradbury, Agnew \& Co., 1888. 2 vol.

Reinach, Salomon. Répertoire de peintures du moyen âge et de la renaissance, 1280-1580. Paris, Leroux, 1905-1923. 6 vol.

- - Répertoire de reliefs grecs et romaines. Paris, Leroux, 1909-1912. 3 vol.

- Répertoire de la statuaire grecque et romaine. Paris, Leroux, 1897-1930. 6 vol.

Repertorium sculptile-typicum, or a complete collection and explanation of the several marks and cyphers by which the prints of the best engravers are distinguished. . . . London, Sam Harding, 1730. (Based on Pellegrino Antonio Orlandi.)

Ricci, Amico. Storia dellarchitettura in Italia dal secolo IV al XVIII. Modena, Pei Tipi della Regio-Ducale Camera, 1857-1859. 3 vol.

Sirigatti, Lorenzo. La pratica di prospettiva. Venice, Girolamo Franceschi, 1596.

Temanza, Tommaso. Vite dei più celebri architetti e scultori veneziani che fiorono nel secolo decimosesto. Venice, C. Palese, 1778.

Tietze, Hans. Die Methode der Kunstgeschichte; ein Versuch. Leipzig, Seeman, 1913.

Vignola, Giacomo. Le due regole della prospettiva prattica . . coi commentarj del Danti. Rome, 1583.

Whately, Thomas. Observations on modern gardening. . . A new edition with notes by Horace (late) Earl of Oxford. London, West and Hughes, 1801.

Zanotti, Eustachio. Trattato teorico-pratico di prospettiva. . . . Bologna, Volpe, 1766.

\section{Art Auction Catalogues}

\section{April 24}

Jones, Col. Charles Colcock, and others. Autographs, engraved portraits and views. Henkels (no. 720) viii, 148 p. front., port. 2 lots Biographical preface.

1897 Jan. 22

Gebbie, George. Oil paintings and engravings. Henkels (no. 777) 10 p. 43 lots.

Jan. 27

Reinhart, Charles Stanley. Oil paintings, water colors and drawings. American Art Galleries. 24 p., front., port. 402 lots. Biographical notes.

1900 Feb. 12

De Magny and others. Paintings and other objects of art. Thomas Galleries. 68 p., illus., 919 lots.

May 7

Elkins, Wm. and others. Furniture and furnishings. Oil Paintings, oriental rugs and other art objects. Thomas Galleries. 48 p. 450 lots.

May 17

Marshall, Thomas Lee. Collection of artist's proof etchings. Line engravings. Henkels (no. 844) 20 p. 422 lots.

1901 Jan. 15

Clark, Dr. Charles E. American portraiture. Fine collection of Washington portraits. Libie. 136 p., front., port., illus. 2057-4 lots. Priced. 
Nov. 20

Krause, Hamilton U. Paintings by foreign and American artists. Davis and Harvey Galleries. 37 p., 175 lots.

Nov. 27

Heysinger, Dr. L. W. and others. Color engravings after G. Morland and by F. Bartolozzi. Etchings, porcelain, paintings. Henkels (no. 870) 18 p. 195 lots.

1902 April 24

Hall, Thomas William. Engravings, etchings, water colors, paintings, etc. Henkels (no. 878) 29 p., illus. 449 lots. Priced.

Dec. 19

Rare engraved portraits of Washington and other American notables. American naval battles. Early American views. Colored caricatures, ete. Henkels (no. 888) 26 p. 246 lots.

\section{JCL ACADEMIC YEAR INSTITUTE}

Recruitment assistance is being sought by Appalachian State University to find participants for the academic year institute for Junior College Librarians which has been funded under Title IIB, HEA. Designed to develop twenty new professionals with strength in the Learning Resource concept and familiarize them with the philosophy of the community junior college, the session will run from September 1969-July 1970. The program leads to the M.A. degree in Library Science. Applicants must hold a bachelor's degree and have completed at least nine quarter hours (six semester hours) of basic undergraduate work in $\mathrm{Li}$ brary Science. The stipend for each participant will be $\$ 75$ a week plus $\$ 15$ a week for each dependent. Most fees will be paid from the grant. Applications for admission must be on file by June 1, 1969.

In the summer of 1970 , twenty additional participants will join the group. Only full-time community junior college librarians are eligible to apply for this phase of the institute, during which a series of "mini-courses" designed to familiarize students with current trends and practices in automation, multimedia utilizations, and management techniques will be presented by visiting lecturers and the Appalachian staff. Stipends are the same as for the earlier part of the program. Applications for admission to this portion must be on file by June 1, 1970 .

For information and application forms, write to Professor Eunice Query, Director, Academic Year Institute for Junior College Librarians,
Appalachian State University, Boone, North Carolina 28607.

\section{ABPC/RTSD PRECONFERENCE}

"New Dimensions in Acquisitions" will be the theme of a $2 \frac{1}{2}$ day Institute June 19 through June 21,1969 , to be held prior to the annual conference of ALA in Atlantic City. The Sponsors of this Institute is the American Book Publishers Council and the Resources and Technical Services Division Joint Committee of the American Library Association.

Innovative approaches to the solutions of library acquisition problems will be emphasized through both traditional print material and the newer non-print materials. Among traditional problems covered in the Institute sessions will be the out-of-print market, periodical subscriptions, gifts and exchanges, and the purchase of paperbacks. Newly emerging techniques for purchasing, such as advance copy plans, blanket orders, and centralized acquisitions will be presented along with modern acquisition techniques using computer processing, the standard book number, and other aspects of scientific management.

The opening address will be by James C. Worthy of the management consultant firm of Cresap, McCormick and Paget. Mr. Worthy's topic will be "Scientific Management" stressing the need for efficient and economical procedures, research experimentation, and testing of acquisitions systems. Mrs. Elizabeth Rodell of Rice University, for seven years executive secretary of the Resources and Technical Services Division, will be the banquet speaker. Her topic "Performance Goals for the Acquisitions Process."

To register, send name and address, with or without the official application blank, with the registration fee of $\$ 41.00$, to ABPC-RTSD Preconference Institute, American Library Association, 50 East Huron Street, Chicago, Illinois 60611. Please make checks payable to the American Library Association. The Institute is limited to 500 attendees.

The Institute will be held in the Dennis Hotel, Atlantic City. For hotel reservations, use the housing form in the January $1969 A L A$ Bulletin. Room reservations will be honored in the block space only until May 1. Request housing in the Lombardy, Mt. Royal or Traymore hotels where space is being reserved for attendees at this institute. Include the statement that you will be attending the ABPCRTSD Preconference Institute. The registration fee covers the costs of luncheons on Thursday and Friday and the banquet Friclay evening. 